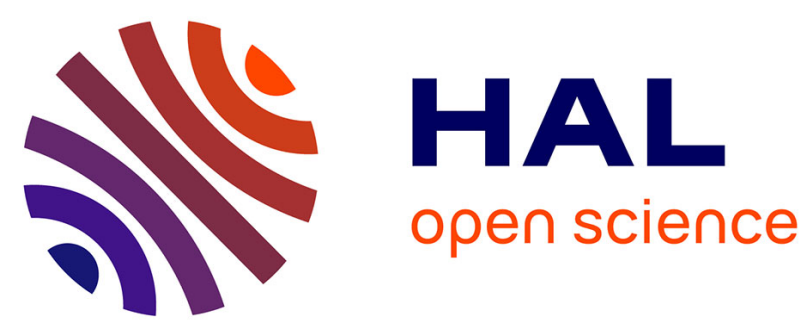

\title{
An assessment of Raphitoma and allied genera (Neogastropoda: Raphitomidae)
}

Giulia Fassio, Valeria Russini, Francesco Pusateri, Riccardo Giannuzzi-Savelli, Tore Høisæter, Nicolas Puillandre, Maria Vittoria Modica, Marco Oliverio

\section{- To cite this version:}

Giulia Fassio, Valeria Russini, Francesco Pusateri, Riccardo Giannuzzi-Savelli, Tore Høisæter, et al.. An assessment of Raphitoma and allied genera (Neogastropoda: Raphitomidae). Journal of Molluscan Studies, 2019, 85 (4), pp.414-425,. 10.1093/mollus/eyz022 . hal-02970454

\section{HAL Id: hal-02970454 \\ https://hal.science/hal-02970454}

Submitted on 18 Oct 2020

HAL is a multi-disciplinary open access archive for the deposit and dissemination of scientific research documents, whether they are published or not. The documents may come from teaching and research institutions in France or abroad, or from public or private research centers.
L'archive ouverte pluridisciplinaire HAL, est destinée au dépôt et à la diffusion de documents scientifiques de niveau recherche, publiés ou non, émanant des établissements d'enseignement et de recherche français ou étrangers, des laboratoires publics ou privés. 


\title{
An assessment of Raphitoma and allied genera (Neogastropoda: Raphitomidae)
}

Giulia Fassio ${ }^{1}$, Valeria Russini ${ }^{1}$, Francesco Pusateri ${ }^{2}$, Riccardo Giannuzzi-Savelli ${ }^{3}$, Tore Høisæter ${ }^{4}$, Nicolas Puillandre $^{5}$, Maria Vittoria Modica ${ }^{6,7}$ and Marco Oliverio ${ }^{1}$

${ }^{1}$ Department of Biology and Biotechnologies “Charles Darwin” Zoology, Viale dell’Università 32, I-00185 Roma, Italy;

${ }^{2}$ Via Castellana, 64 - 90135 Palermo;

${ }^{3}$ Via Mater Dolorosa, 54 - 90146 Palermo;

${ }^{4}$ University of Bergen, Museum of Natural History, P.O. Box 7800 (Thormøhlens gate 53A), N5020 Bergen, Norway;

${ }^{5}$ Institut de Systématique Evolution Biodiversité (ISYEB), Muséum National d'Histoire Naturelle, CNRS, Sorbonne Université, EPHE, 57 Rue Cuvier, CP 26, 75005 Paris, France;

${ }^{6}$ Department of Integrative Marine Ecology, Stazione Zoologica Anton Dohrn, Naples, Italy; and 7UMR5247, University of Montpellier, France

Running head: Systematics of Raphitoma

(Received 9 January 2019; editorial decision 9 April 2019)

Correspondence: M. Oliverio; email: marco.oliverio@uniroma1.it

\begin{abstract}
The systematics of several Eastern Atlantic conoidean species, traditionally ascribed to the genus Raphitoma Bellardi, 1847, are revised on the basis of DNA sequence data from three gene regions (cytochrome $c$ oxidase subunit I, 16S rRNA and 12S rRNA). We assign genus ranking to three major lineages (Raphitoma, Cyrillia Kobelt, 1905 and Leufroyia Monterosato, 1884), and suggest that two West African species belong in the subgenus Daphnella (Paradaphne) Laseron, 1954. A new classification, based on molecular systematics and critical study of morphology, is provided for of all Eastern Atlantic and Mediterranean species that are currently ascribed to Raphitoma s. $l$. The genus Clathromangelia Monterosato, 1884 is confirmed as belonging to Raphitomidae. Phylogenetic relationships and genetic distances suggest that $R$. maculosa Høisæter, 2016 and $R$. obesa Høisæter, 2016 may be deviating morphotypes of $R$. bicolor (Risso, 1826) and Cyrillia aequalis (Jeffreys, 1867), respectively.
\end{abstract}




\section{INTRODUCTION}

The Raphitomidae are probably the most diverse family of Conoidea, in terms of species richness, ecological range and anatomy (Kantor \& Taylor, 2002; Bouchet et al., 2011). The name Raphitomidae Bellardi, 1875 is based on the genus Raphitoma Bellardi, 1847. At the time of its introduction, this genus comprised 34 fossil and Recent species (Bellardi, 1847: 85) that had previously been classified in various genera, such as Pleurotoma and Clathurella. The genus Raphitoma has been particularly well studied in the northeastern Atlantic and Mediterranean, where a recent estimate (Giannuzzi-Savelli et al., 2018) suggested that over 50 extant species occur. These snails, which are usually active at night, live mostly in marine soft-bottom environments at depths ranging from 0-100 $\mathrm{m}(R$. pseudohystrix has been collected at $700 \mathrm{~m})$. While they inhabit a wide variety of habitats ranging from coastal bioclastic coarse sands to muddy bioclastic coarse sands, they also occur in sandy pockets, between rocks and in seagrass meadows, with individuals hiding buried under sand or concealed under stones and in crevices during the day. The limits of the genus are still under debate and Raphitoma s. $l$., as currently conceived, comprises species with the following shell characters: turreted to biconic-pupoidal shape; small to medium size $(5-25 \mathrm{~mm})$ in relation to the family Raphitomidae as whole; a frequently keeled last whorl; protoconch consisting of 3-4.5 whorls when multispiral, with the typical raphitomid diagonally cancellate sculpture (Giannuzzi-Savelli et al., 2018; Manousis et al., 2019; Fig. 1). While available data on the morphology of the soft parts are scarce, they nonetheless suggest that there is substantial variation in the anatomy of the foregut. Some species, such as $R$. villaria and $R$. linearis, have neither a radula nor a venom gland. Others, such as $R$. purpurea and $R$. leufroyi, do have a radula, a venom gland or both (Sheridan et al., 1973: 177; Pusateri \& Giannuzzi-Savelli, 2008: 124). The arrangement of the foregut has been described for $R$. purpurea (Miller, 1989: 173; Sheridan et al., 1973: 177), but there is a different arrangement in $R$. linearis and $R$. leufroyi, where a rhynchodeal introvert or pseudoproboscis is present (Taylor et al., 1993: 128; Sheridan et al., 1973: 178). The systematic implications of this variability are still unknown, and the problem is further complicated by the lack of a comprehensive phylogenetic framework for the family Raphitomidae.

The type species of Raphitoma is R. histrix Bellardi, 1847 [ex Pleurotoma hystrix Cristofori $\&$ Jan, 1832, nomen nudum] by subsequent designation (Monterosato, 1872: 54). Raphitoma histrix as almost always conceived is a fossil species (Miocene-Pleistocene) and has a complex nomenclatural history that has been summarized by Giannuzzi-Savelli et al. (2018: 9; see also Dall, 1918: 316; van Aartsen et al., 1984: 89-90; Rolán et al., 1998: 105). Raphitoma pseudohystrix (Sykes, 1906) appears to be the extant closest relative of $R$. histrix; while the teleoconch of the former is almost identical to that of the latter, the protoconch in the extant species is paucispiral whereas in $R$. histrix it is multispiral.

According to current taxonomy, at least eight nominal genera are included in the synonymy of Raphitoma s. l. (see Systematic Descriptions below).

Høisæter (2016) argued that DNA-sequence-based phylogenetic studies would most likely show that Raphitoma $s$. $l$. consists of several genus-level taxa, for which available names could be employed. By carrying out a molecular phylogenetic study of the raphitomids, we seek to explore this issue. Our dataset consists of representatives of at least 13 recognized genera of Raphitomidae (18\% of the c. 70 genera known for this family; MolluscaBase, 2018), as well as two species of Clathromangelia, a genus that has been considered to be a raphitomid (Oliverio, 1995) or a clathurellid (Bouchet et al., 2011). The dataset also includes 14 species which, on the basis of morphology, have been ascribed to Raphitoma $s . \quad l$; these include the type species of Cenodagreutes, Cyrillia, Leufroyia, Lineotoma and Philbertia, the apparent closest relatives of the type species of Cordieria and Cyrtoides, and the closest extant relative of the (fossil) type species of Raphitoma. 
Table 1. List of material used in the study along with voucher registration numbers, collection localities, GenBank accession numbers for sequences and relevant references.

\section{Taxon}

Raphitomidae

Cyrillia aequalis (Jeffreys, 1867)

Cyrillia aequalis (Jeffreys, 1867)

Cyrillia aequalis (Jeffreys, 1867)

Cyrillia aequalis (Jeffreys, 1867)

Cyrillia aequalis (Jeffreys, 1867)

Cyrillia linearis (Montagu, 1803)

Cyrillia linearis (Montagu, 1803)

Cyrillia obesa (Høisæter, 2016)

Clathromangelia granum (Philippi, 1844)

Clathromangelia loiselieri Oberling, 1970

Daphnella sp.

Daphnella (Paradaphne) corimbensis Rolán, Otero-Schmitt \& Fernandes, 1998

Eucyclotoma cymatodes (Hervier, 1897)

Hemilienardia acinonyx Fedosov, Stahlschmidt, Puillandre, Aznar-Cormano \& Bouchet, 2017

Hemilienardia calcicincta (Melvill \& Standen, 1895)

Leufroyia concinna (Scacchi, 1836)

Leufroyia concinna (Scacchi, 1836)

Leufroyia concinna (Scacchi, 1836)

Leufroyia concinna (Scacchi, 1836)

Leufroyia concinna (Scacchi, 1836)

Leufroyia leufroyi (Michaud, 1828)

\section{Voucher ID Locality}

ZMBN

Norway, $60^{\circ} 13^{\prime} 48^{\prime \prime} \mathrm{N} 5^{\circ} 12^{\prime} \mathrm{E}$

ZMBN-E-345-

$66 \mathrm{a}$

ZMBN-E-345- Norway, $60^{\circ} 18^{\prime} \mathrm{N} 5^{\circ} 10^{\prime} 48^{\prime \prime} \mathrm{E}$

MT09383 North Sea, $57^{\circ} 53^{\prime} 56.4^{\prime \prime} \mathrm{N} 0^{\circ} 54^{\prime} 57.6^{\prime \prime} \mathrm{W}$

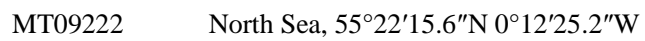

BAU-2234 Italy, Giannutri Is., loc. Le Cerniette, $42^{\circ} 15^{\prime} 10^{\prime \prime} \mathrm{N}$ $011^{\circ} 05^{\prime} 32^{\prime \prime} \mathrm{E}$

BAU-2912.1

ZMBN-E-37-

68

BAU-3082.1 $20 \mathrm{~m}$

(Ialy, Scilla, $38^{\circ} 15^{\prime 2} 3^{\prime \prime} \mathrm{N} 15^{\circ} 42^{\prime 4} 5^{\prime \prime} \mathrm{E}, 35-37 \mathrm{~m}$

BAU-1545

MNHN-IM-

2007-17927

BAU-2989

MNHN-IM-

2007-17903

MNHN-IM-

2009-33593

2007-17861

ZMBN-H-3-

$69 \mathrm{a}$

ZMBN-E-23-

67

ZMBN-

ZMBN-

BAU-2254.1

BAU-2237

BAU-2240.1
GenBank accession numbers

COI

16S rRNA

12S rRNA

\begin{tabular}{|c|c|c|c|}
\hline JF834219 & JF834214 & & Høisæter (2016) \\
\hline JF834221 & & & Høisæter (2016) \\
\hline JF834225 & & & Høisæter (2016) \\
\hline KR084567 & & & Barco et al. (2016) \\
\hline KR084390 & & & Barco et al., 2016 \\
\hline MK410632 & MK410605 & MK410585 & This study \\
\hline MK410623 & MK410599 & & This study \\
\hline JF834220 & MK410610 & & Høisæter (2016); this study \\
\hline MK410624 & MK410600 & & This study \\
\hline MK410627 & MK410601 & & This study \\
\hline EU015740 & HQ401674 & HQ401607 & Puillandre et al. (2008) \\
\hline MK410635 & MK410608 & MK410587 & This study \\
\hline EU015678 & HQ401676 & HQ401610 & Puillandre et al. (2008) \\
\hline KX233238 & KX233249 & & Fedosov et al. (2017) \\
\hline EU015683 & HQ401684 & HQ401618 & Puillandre et al. (2008) \\
\hline JF834222 & & & Høisæter (2016) \\
\hline JF834223 & & & Høisæter (2016) \\
\hline JF834224 & JF834218 & & Høisæter (2016) \\
\hline MK410616 & MK410593 & MK410580 & This study \\
\hline MK410633 & MK410606 & & This study \\
\hline MK410613 & & & This study \\
\hline
\end{tabular}


'Phymorhynchus' sp.

Pleurotomella sp.

Pseudodaphnella aureotincta (Hervier, 1897)

Raphitoma bicolor (Risso, 1826)

Raphitoma cordieri (Payraudeau, 1826)

Raphitoma cordieri (Payraudeau, 1826)

Raphitoma densa (Monterosato, 1884)

Raphitoma densa (Monterosato, 1884)

Raphitoma horrida (Monterosato, 1884)

Raphitoma horrida (Monterosato, 1884)

Raphitoma horrida (Monterosato, 1884)

Raphitoma laviae (Philippi, 1844)

Raphitoma laviae (Philippi, 1844)

Raphitoma maculosa Høisæter, 2016

Raphitoma philberti (Michaud, 1829)

Raphitoma philberti (Michaud, 1829)

Raphitoma philberti (Michaud, 1829)

Raphitoma philiberti (Michaud, 1829)

Raphitoma pseudohystrix (Sykes, 1906)

Raphitoma purpurea (Montagu, 1803)

Raphitoma purpurea (Montagu, 1803)

Raphitoma purpurea (Montagu, 1803)

'Raphitoma' rubroapicata (E. A. Smith, 1885)

'Raphitoma' sp

Rimosodaphnella sp.

Spergo sp.

Taranis sp.
BAU-2262.1

BAU-2262.2

BAU-2257.1

BAU-1895

BAU-2264.1

BAU-1900

BAU-1906.1

BAU-2253.1

BAU-2246.1

ZMBN-

040809_X

BAU-2365.1

BAU-2258.1

BAU-1893.1

BAU-3046

BAU-3205

BAU-2337.1

BAU-2337.3

BAU-2338

MNHN-IM

2007-17890

MNHN-IM-

2007-17882

2007-17836

MNHN-IM-

2007-17841

MNHN-IM-

2007-42296
Sardinia, Villasimius, $39^{\circ} 07^{\prime} 43^{\prime \prime} \mathrm{N} 9^{\circ} 32^{\prime} 17^{\prime \prime} \mathrm{E}$

Mid-Cayman Spreading Centre, Beebe vent chimneys

New Caledonia, Lansdowne, EBISCO, 204'52.32"S

$160^{\circ} 20^{\prime} 2.34^{\prime \prime} \mathrm{E}$

Philippines, Pamilacan Is., PANGLAO 2004, $9^{\circ} 29^{\prime} 24^{\prime \prime N}$ $123^{\circ} 56^{\prime} 6^{\prime \prime} \mathrm{E}$

France, St. Maxime, $43^{\circ} 18^{\prime} 49^{\prime \prime} \mathrm{N} 6^{\circ} 40^{\prime} 22^{\prime \prime} \mathrm{E}$, intertidal

Croatia, Sukosan, $44^{\circ} 02^{\prime} 04^{\prime \prime} \mathrm{N} 15^{\circ} 18^{\prime} 57^{\prime \prime} \mathrm{E}$

Croatia, Sukosan, $44^{\circ} 02^{\prime} 04^{\prime \prime N} 15^{\circ} 18^{\prime} 57^{\prime \prime} \mathrm{E}$

Croatia, Sukosan, $44^{\circ} 02^{\prime} 10^{\prime \prime} \mathrm{N} 15^{\circ} 18^{\prime} 55^{\prime \prime} \mathrm{E}$

Italy, Torre Colimena, $40^{\circ} 17^{\prime} 39^{\prime \prime} \mathrm{N} 17^{\circ} 45^{\prime} 17^{\prime \prime} \mathrm{E}, 3 \mathrm{~m}$

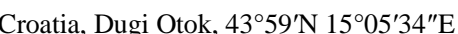

Corsica, Tour d'Ancone, 42 $02^{\prime} 36^{\prime \prime} \mathrm{N} 8^{\circ} 43^{\prime 2} 20^{\prime \prime} \mathrm{E}, 10 \mathrm{~m}$

France, St. Maxime, $43^{\circ} 18^{\prime} 49^{\prime \prime} \mathrm{N} 6^{\circ} 40^{\prime} 22^{\prime \prime} \mathrm{E}$, intertidal

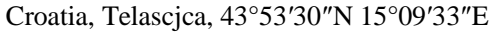

Croatia, Zaton, $44^{\circ} 13^{\prime} 07^{\prime \prime} \mathrm{N} 15^{\circ} 09^{\prime} 41^{\prime \prime} \mathrm{E}$

Norway, $60^{\circ} 18^{\prime} \mathrm{N} 5^{\circ} 07^{\prime} 48^{\prime \prime} \mathrm{E}$

Croatia, Biograd, 435' $51^{\prime \prime} \mathrm{N} 15^{\circ} 26^{\prime} 42^{\prime \prime} \mathrm{E}$

Croatia, Vrsi, $44^{\circ} 16^{\prime} 56^{\prime \prime} \mathrm{N} 15^{\circ} 12^{\prime} 35^{\prime \prime} \mathrm{E}$

Greece, Limnos, Koukonisi Bay, 39 $53^{\circ} 07^{\prime \prime} \mathrm{N}$

$25^{\circ} 16^{\prime} 16^{\prime \prime} \mathrm{E}$

Greece: Astypalea Is., Vai, VYLLAS 2017, 36 $35^{\prime} 13^{\prime \prime} \mathrm{N}$

"E, 1-6 $\mathrm{m}$, under rocks

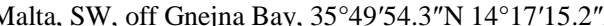
$220 \mathrm{~m}$, fine sand and mud

France, Ploubazlanec, $48^{\circ} 48^{\prime} 5^{\prime \prime} \mathrm{N} 3^{\circ} 00^{\prime} 10^{\prime \prime} \mathrm{W}$, intertida

France, Ploubazlanec, $48^{\circ} 48^{\prime} 5^{\prime \prime} \mathrm{N} 3^{\circ} 00^{\prime} 10^{\prime \prime} \mathrm{W}$, intertidal

France, Ploubazlanec, $48^{\circ} 48^{\prime} 5^{\prime \prime} \mathrm{N} 3^{\circ} 00^{\prime} 10^{\prime \prime} \mathrm{W}$, intertidal

Philippines, Panglao Is., off Momo beach, PANGLAO

2004, 9 ${ }^{\circ} 36^{\prime} 30^{\prime \prime} \mathrm{N} 123^{\circ} 45^{\prime} 18^{\prime \prime} \mathrm{E}$

Philippines, Balicasag Is., PANGLAO 2004, 9³0'54"N

$123^{\circ} 41^{\prime} 12^{\prime \prime} \mathrm{E}$

New Caledonia, Koumac Sector, around Ouaco, BOA1,

$20^{\circ} 48^{\prime} 42^{\prime \prime} \mathrm{S} 164^{\circ} 24^{\prime} 12^{\prime \prime} \mathrm{E}$

New Caledonia, SE Fairway, EBISCO, 21032'36"S

$162^{\circ} 28^{\prime} 36^{\prime \prime} \mathrm{E}$

Philippines, AURORA 2007, 15 56 $34.2^{\prime \prime} \mathrm{N}$

$121^{\circ} 50^{\prime} 11.4^{\prime \prime} \mathrm{E}$
MK410628

MK41058

KJ566952 KM979537

EU015657 HQ401701

EU015700 HQ401688

MK410630 MK410603

MK410619 MK410595

MK410625

MK410617 MK410594

MK410629 MK410602

MK410620 MK410596

MK410631 MK410604

MK410612 MK410590

MK410615 MK410592

MK410614 MK41059

MK410638

MK410622 MK410598

MK410618

MK410611

MK410636

MK410637 MK410609

MK410621 MK410597

MK410626

MK410634 MK410607

EU015713 HQ401703

EU015704

EU015645 HQ401704

EU015650 HQ401682

HQ401584 HQ401707

MK410582

MK41058

MK41058

MK410577

(2)

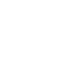

HQ401640

HQ401624

MK410579

MK410578

$\begin{array}{ll} & \text { This study } \\ & \text { This study } \\ & \text { This study } \\ \text { MK410588 } & \text { This study } \\ \text { MK410589 } & \text { This study } \\ & \text { This study } \\ & \text { This study } \\ \text { MK410586 } & \text { This study } \\ \text { HQ401642 } & \text { Puillandre } \text { et al. (2008) } \\ & \text { Puillandre } \text { et al. (2008) } \\ & \text { Puillandre } \text { et al. (2008) } \\ \text { HQ401616 } & \text { Puillandre } \text { et al. (2008) } \\ & \text { Puillandre } \text { et al. (2011) }\end{array}$

Plouviez et al. (2015)

Puillandre et al. (2008)

Puillandre et al. (2008)

This study

study

This study

This study

This study

This study

This study

This study

This study

This study

Høisæter (2016); this study 
MNHN-IM- Papua New Guinea, Bismarck Archipelago, W Kairiru I.,

2013-52046

MNHN-IM

2007-17845

MNHN-IM-

2007-17924

MNHN-IM-

2007-17883

$3^{\circ} 19^{\prime} 26.4^{\prime \prime} \mathrm{S} 143^{\circ} 27^{\prime} 14.4^{\prime \prime} \mathrm{E}$

New Caledonia, SE Fairway, EBISCO, $21^{\circ} 28^{\prime} 8^{\prime \prime S}$

$162^{\circ} 33^{\prime} 54^{\prime \prime} \mathrm{E}$

Salomon Is., SE Isabel, SALOMON 2, $8^{\circ} 16^{\prime} 54^{\prime \prime} \mathrm{S}$

$159^{\circ} 59^{\prime} 42^{\prime \prime} \mathrm{E}$

Philippines, Balicasag Is., PANGLAO 2004, 9³0'54"N

Veprecula cf. spanionema (Melvill, 1917)

\section{Clathurellidae}

Lienardia crassicostata (Pease, 1860)

NA

Lienardia nigrotincta (Montrouzier in Souverbie \& Montrouzier, 1873)

Nannodiella ravella (Hedley, 1922)

\section{Mangeliidae}

Anticlinura sp. Thiele, 1934

Propebela cf. scalaris (Møller, 1842)

Toxicochlespira pagoda Sysoev \& Kantor, 1990

Conidae

Conus radiatus Gmelin, 1791

Conus textile Linnaeus, 1758

Conus ventricosus Gmelin, 179
MNHN-IM-

2007-42607

MNHN-IM-

2007-17904

Vanuatu, E Luganville, Segond Channel, SANTO 2006

$15^{\circ} 30^{\prime} 58^{\prime \prime} \mathrm{S} 167^{\circ} 11^{\prime} 52^{\prime \prime} \mathrm{E}$

Philippines, Panglao Is., off San Isidro, PANGLAO

$2004,9^{\circ} 33^{\prime} 54^{\prime \prime} \mathrm{N} 123^{\circ} 50^{\prime} 30^{\prime \prime} \mathrm{E}$

MNHN-IM- Salomon Is., Sta Isabel, SALOMON 2, $8^{\circ} 47^{\prime} 0^{\prime \prime}$

2007-42513

MNHN-IM- Norway, Hornsund, Svalbard

MNHN-IM- Salomon Is., Choiseul, SALOMON 2, 6037'12.6"S

$2007-17925$ $156^{\circ} 12^{\prime} 44.4^{\prime} \mathrm{E}$

MNHN-IM- $\quad$ Philippines, Bohol Is., Ubajan, PANGLAO 2004,

2007-30883

MNHN-IM-

$9^{\circ} 41^{\prime} 30^{\prime \prime} \mathrm{N} 12350^{\prime} 60^{\prime \prime} \mathrm{E}$

Vanuatu, NW Aésé Is., SANTO 2006, 15²5'7"S

Djerba, Tunisia
Salomon Is., Sta Isabel, SALOMON 2, $8^{\circ} 47^{\prime} 0^{\prime \prime} \mathrm{S}$
$159^{\circ} 37^{\prime} 54^{\prime \prime} \mathrm{E}$

$\begin{array}{llll}\text { KR087296 } & \text { KR088045 } & \text { KR087382 } & \text { Fedosov } \text { et al. (2015) } \\ \text { EU015654 } & \text { HQ401708 } & \text { HQ401646 } & \text { Puillandre } \text { et al. (2008) } \\ \text { EU015736 } & \text { FJ868138 } & \text { FJ868124 } & \text { Puillandre } \text { et al. (2008) } \\ \text { EU015705 } & \text { HQ401717 } & \text { HQ401654 } & \text { Puillandre } \text { et al. (2008) } \\ \text { JF823629 } & \text { JF823611 } & \text { JF823590 } & \text { Cabang } \text { et al. (2011) } \\ \text { HQ401575 } & \text { HQ401666 } & \text { HQ401599 } & \text { Puillandre } \text { et al. (2011) } \\ \text { EU015679 } & \text { HQ401698 } & \text { HQ401634 } & \text { Puillandre } \text { et al. (2008) } \\ & & & \\ \text { HQ401572 } & \text { HQ401660 } & \text { HQ401590 } & \text { Puillandre } \text { et al. (2011) } \\ \text { HQ401582 } & \text { HQ401699 } & \text { HQ401635 } & \text { Puillandre } \text { et al. (2011) } \\ \text { EU015738 } & \text { HQ401711 } & \text { HQ401649 } & \text { Puillandre } \text { et al. (2008) } \\ & & & \\ \text { KJ550437 } & \text { KJ550900 } & \text { KJ551133 } & \text { Puillandre } \text { et al. (2014) } \\ \text { KJ550497 } & \text { KJ550930 } & \text { KJ551134 } & \text { Puillandre } e \text { t al. (2014) } \\ \text { KJ550006 } & \text { KJ550745 } & \text { KJ551370 } & \text { Puillandre } e t \text { al. (2014) }\end{array}$

KJ550006 KJ550745 KJ551370

Puillandre et al. (2014)

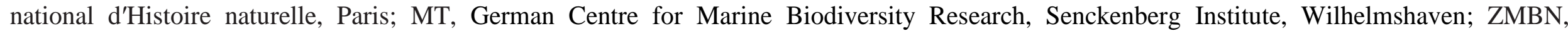

University Museum of Bergen Natural History Collections. NA indicates that specimen registration data were not available. 


\section{MATERIAL AND METHODS}

The dataset is composed of 62 specimens representing 14 raphitomid genera from the Mediterranean Sea, North Sea and Indo-Pacific region. DNA sequence data were generated by us for 28 of these specimens; sequence data for the remaining individuals were obtained from GenBank (Table 1). The specimens sampled included 17 species ascribed to the genus Raphitoma s. $l$ : Raphitoma aequalis, $R$. bicolor, $R$. concinna, $R$. cordieri, $R$. corimbensis, $R$. densa, $R$. horrida, $R$. laviae, $R$. leufroyi, $R$. linearis, $R$. maculosa, $R$. obesa, $R$. philberti, $R$. pseudohystrix, $R$. purpurea, $R$. rubroapicata, an unidentified Raphitoma sp. The dataset also included 13 other raphitomid or putative raphitomid genera: Clathromangelia Monterosato, 1884; Hemilienardia Boettger, 1895; Eucyclotoma Boettger, 1895; Rimosodaphnella Cossmann, 1916; Veprecula Melvill, 1917; Pleurotomella Verrill, 1872; Phymorhynchus Dall, 1908; Pseudodaphnella Boettger, 1895; Spergo Dall, 1895; Taranis Jeffreys, 1870; Thatcheria Angas, 1877; Daphnella Hinds, 1844; and Teretiopsis Kantor \& Sysoev, 1989. Specimens from two other conoidean families were also included. These groups are the Clathurellidae (the putative sister group of the raphitomids) and the Mangeliidae (considered to be sister to the clade comprising the Raphitomidae and Clathurellidae) (Abdelkrim et al., 2018). The outgroup comprised three species of Conidae.

DNA was isolated from a piece of foot tissue following a standard proteinase $\mathrm{K} / \mathrm{phenol}-$ chloroform extraction protocol (Oliverio \& Mariottini, 2001). Three mitochondrial gene fragments were amplified: the 658-bp barcode region of cytochrome $c$ oxidase subunit I (COI), with universal primers LCO1490 and HC02198 (Folmer et al., 1994); a c. 500-bp region of the 16S rRNA gene, with primers 16SA (Palumbi, 1996), and CGLeuR (Hayashi, 2003) or 16SH (Espiritu et al., 2001); and a $c .600 \mathrm{bp}$ region of the $12 \mathrm{~S}$ rRNA, with primers 12SI and 12SIII (Oliverio \& Mariottini, 2001). The following PCR conditions were used: initial denaturation $\left(94{ }^{\circ} \mathrm{C}\right.$ for $\left.4 \mathrm{~min}\right)$; 35 cycles of denaturation $\left(94{ }^{\circ} \mathrm{C}\right.$ for $\left.30 \mathrm{~s}\right)$; annealing $\left(48-51{ }^{\circ} \mathrm{C}\right.$ for COI, $52{ }^{\circ} \mathrm{C}$ for $16 \mathrm{~S}$ rRNA, $58-60{ }^{\circ} \mathrm{C}$ for $12 \mathrm{~S}$ rRNA for $40 \mathrm{~s}$ ) and extension $\left(94^{\circ} \mathrm{C}\right.$ for60"); final extension $\left(72{ }^{\circ} \mathrm{C}\right.$ for $\left.10 \mathrm{~min}\right)$. Amplicons were purified using Exosap-IT (USB Corporation) and sequenced by Macrogen Inc. (The Netherlands).

COI sequences were aligned using Geneious v. 11 (Kearse et al., 2012). Sequences for $16 \mathrm{~S}$ rRNA and 12S rRNA were aligned with the online version of MAFFT v. 7 (Katoh et al., 2017, Kuraku et al., 2013), using the Q-INS-I algorithm. Ambiguous regions in the 16SrRNA and 12S rRNA alignments were discarded using Gblocks v. 0.91b (Castresana, 2000) with respectively 76\% and $64 \%$ of the original positions being retained; we used default options.

In our phylogenetic analyses we used the three single-gene datasets as well as a combined dataset $(\mathrm{COI}+12 \mathrm{~S}$ rRNA+16S rRNA). The Bayesian information criterion (BIC) implemented in jModelTest v. 2.1.7 (Posada, 2008) was used to identify the best substitution models and parameters for each gene partition; the substitution model selected for all datasets was GTR+I+G. Phylogenetic analyses were performed using maximum likelihood (ML) and Bayesian approaches; all analyses were run on the CIPRES Science Gateway (Miller Pfeiffer \& Schwartz, 2010). ML analyses were done using RAxML v. 8 (Stamatakis, 2014). Branch support estimates were based on 1000 bootstrap replicates. Bayesian analyses were performed using MrBayes v. 3.2.3 (Huelsenbeck \& Ronquist, 2001); analyses were run for $10^{7}$ generations, with trees sampled every 1000 generations and $25 \%$ burn-in (for all other parameters we used default settings). Convergence of MCMC was assumed to have occurred when the effective sample size was $>200$ and the potential scale reduction factor was $\sim 1$, as calculated with Tracer v. 1.6. Branches with bootstrap values (BS) $\geq 70 \%$ and posterior probabilities (PP) $\geq 0.95$ were considered to be strongly supported.

\section{RESULTS}

The final datasets consisted of 62 COI sequences, 47 16S rRNA sequences and 34 12S rRNA sequences. Single-gene and combined analyses yielded topologically similar trees. The trees 
obtained from the concatenated dataset tended to show higher branch support values, and this was especially so in the case of the Bayesian analysis (Fig. 2, Supplementary Material Figs S1-S7). The three families Raphitomidae, Clathurellidae and Mangeliidae together formed a strongly supported monophyletic group. Our Bayesian analyses recovered the Clathurellidae as sister to the raphitomid clade, but this relationship was not strongly supported (e.g. PP $=0.71$ for combined dataset, Fig. 2). We found consistently strong support for the monophyly of the Raphitomidae.
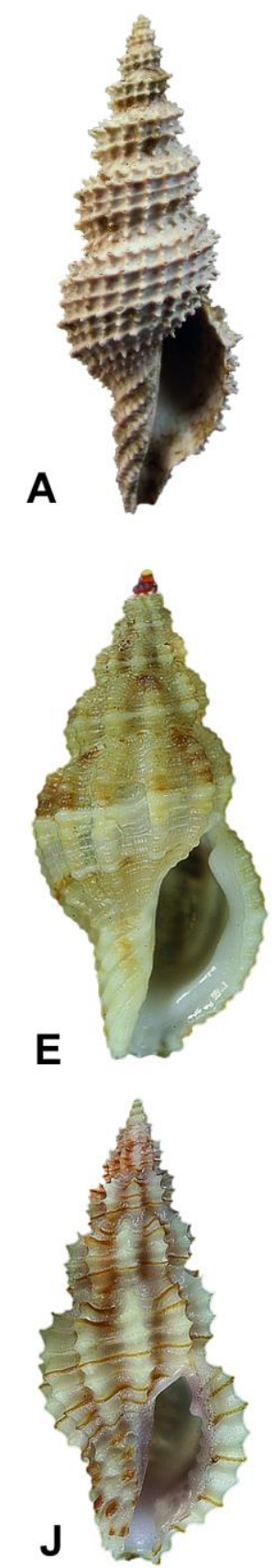
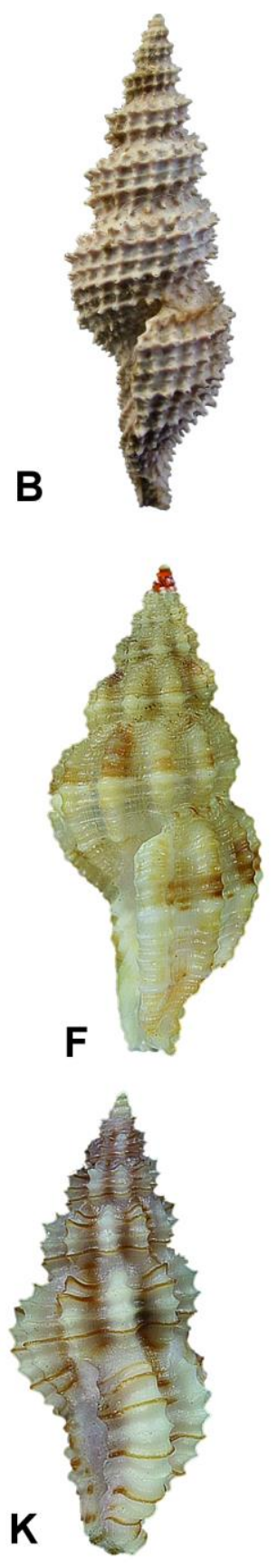
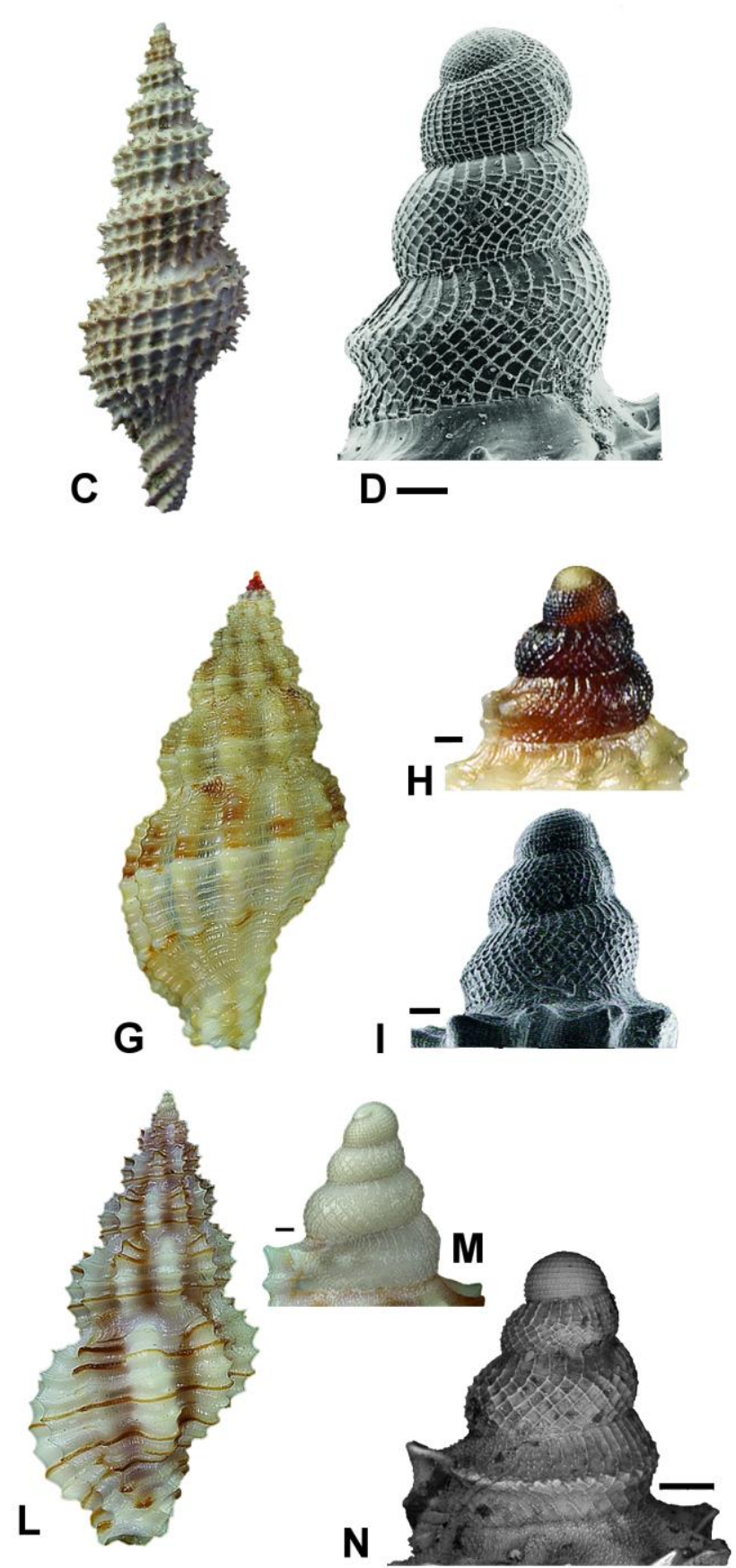

Figure 1. Type species of Raphitomidae illustrated by representative shell material. A-D. Raphitoma hystrix Bellardi, 1847, the type species of the genus Raphitoma Bellardi, 1847. Neotype (MRSN n. cat. 011.16.008) from Colli Astesi (Italy; Pliocene, Piacentian); shell height is $17.6 \mathrm{~mm}$. E-I. Leufroyia leufroyi (Michaud, 1828), the type species of the genus Leufroyia Monterosato, 1884. Shell from a depth of $40 \mathrm{~m}$, Ile Rousse (Corsica); shell height is $11 \mathrm{~mm}$. J-M. Cyrillia linearis (Jeffreys, 1867), the type species of the genus Cyrillia Kobelt, 1905. Shell from a depth of $1 \mathrm{~m}$, Lastovo (Croatia); shell height is $7 \mathrm{~mm}$. All scale bars are $100 \mu \mathrm{m}$ in length. 
Within the Raphitomidae, specimens of the genus Raphitoma s. l. were distributed across five clades. Raphitoma leufroyi and $R$. concinna were strongly supported as sister species $(\mathrm{BS}=99 \%$, $\mathrm{PP}=1$ ); these two species together with $R$. rubroapicata and the genus Hemilienardia formed a clade that was strongly supported in the ML analysis $(\mathrm{BS}=85 \%)$, but not in the Bayesian analysis $(\mathrm{PP}=0.94)$. The Bayesian analysis showed strong support for the clade comprising $R$. corimbensis, Rimosodaphnella and Veprecula ( $\mathrm{PP}=0.95)$, and the clade comprising the 'Raphitoma' sp. from the Philippines (MNHN-IM-2007-17882) and Eucyclotoma cymatodes ( $\mathrm{PP}=0.99)$. Relationships between these two clades and other raphitomids were unresolved. The two species of Clathromangelia, which were strongly supported as sister taxa $(\mathrm{BS}=99 \%, \mathrm{PP}=1)$, formed a clade with Pseudodaphnella, Eucyclotoma and a 'Raphitoma' sp. (MNHN-IM-2007-17882) in the Bayesian analysis $(\mathrm{PP}=1)$. This clade was nested within the raphitomid clade.

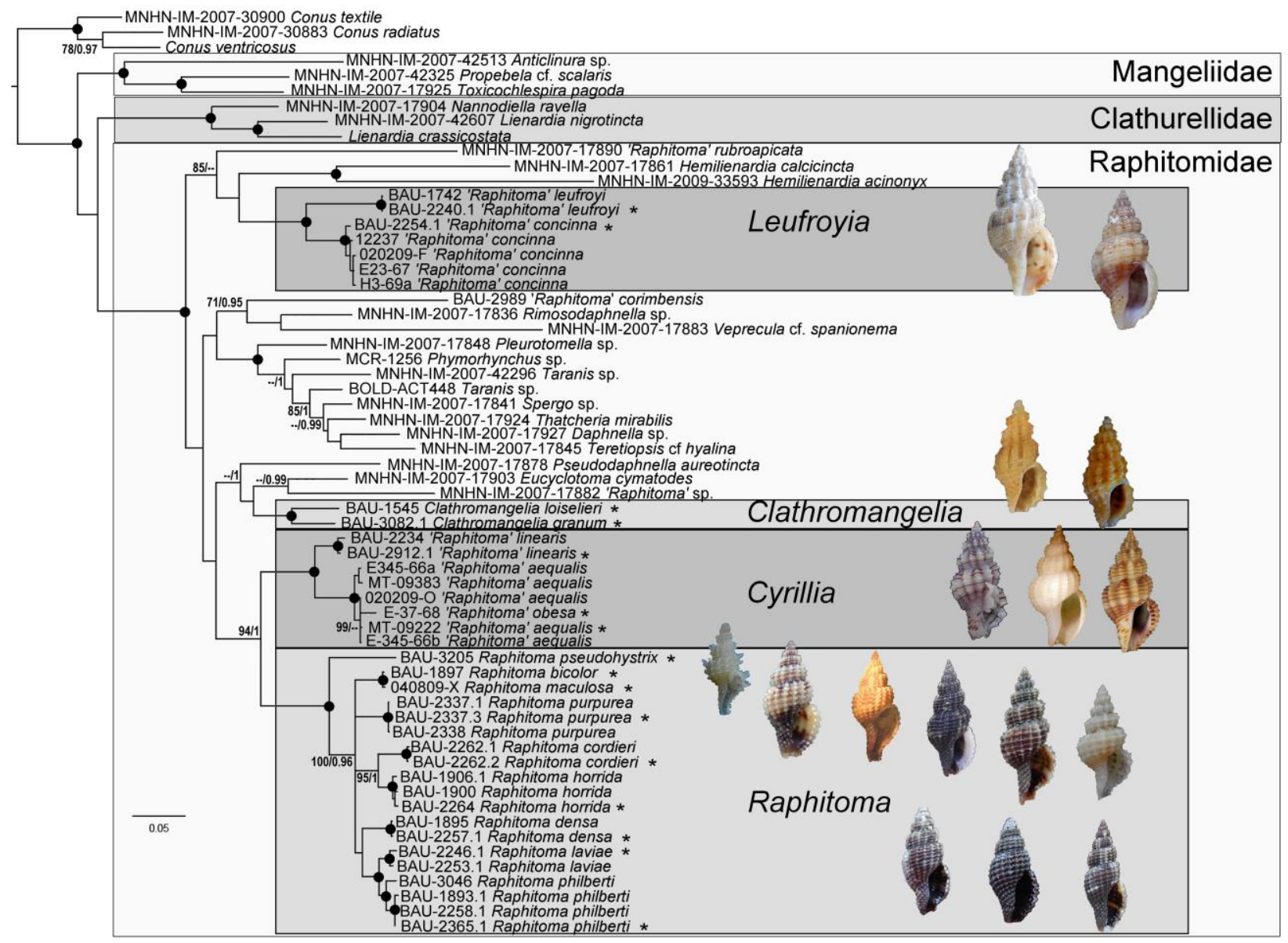

Figure 2. Phylogenetic relationships among conoideans, as illustrated by the Bayesian majority consensus tree of the combined dataset $(\mathrm{COI}+12 \mathrm{~S}$ rRNA+16S rRNA). The tree is rooted on a composite outgroup comprising three species of Conus. Support values are given as posterior probabilities for the Bayesian analysis (only values $\geq 0.95$ are shown) and as bootstrap percentages for the ML analysis (only values $\geq 70 \%$ are shown). Closed circles indicate branches with bootstrap support $>95 \%$ and posterior probabilities $>0.98$. Shells of vouchers are indicated by asterisks and are not to scale. Scale bar indicates substitutions per site. 
Most of the specimens ascribed to Raphitoma s. $l$. formed a strongly supported clade only in the Bayesian analyses of the $12 \mathrm{~S}$ rRNA, 16S rRNA and combined datasets (PP $=1$ in Fig. 1; see also Supplementary Material Figs S1, S3, S5); this large clade was not strongly supported in most of the remaining analyses (Supplementary Material Figs S2, S4, S6, S7). However we consistently found strong support for two lineages within this clade. The first sublineage comprised Raphitoma linearis, $R$. aequalis and $R$. obesa $(\mathrm{BS}=100 \%, \mathrm{PP}=1)$. The second sublineage consisted of $R$. pseudohystrix, $R$. bicolor, $R$. cordieri, $R$. densa, $R$. horrida, $R$. laviae, $R$. maculosa, $R$. philberti and $R$. purpurea $(\mathrm{BS}=100 \%, \mathrm{PP}=1)$; in this sublineage, $R$. pseudohystrix was sometimes strongly supported as sister to the clade containing the other members of the sublineage.

\section{DISCUSSION}

The Bayesian analyses showed a sister-group relationship between the Raphitomidae and Clathurellidae; this agrees with the most recent phylogenetic hypotheses on the Conoidea, which are based on the most extensive taxon sampling achieved to date (Puillandre et al., 2011, Abdelkrim et al., 2018), but was not strongly supported. The genus Clathromangelia was confirmed as belonging to the Raphitomidae, as has previously been suggested on the basis of anatomical and protoconch data (Oliverio, 1995). Our finding that Clathromangelia is a member of a clade containing Pseudodaphnella and Eucyclotoma, is not surprising given the similarity in shell morphology between these three taxa, and particularly between Clathromangelia and Pseudodaphnella. This study shows that most of the species ascribed to Raphitoma $s$. $l$. fall into three clades, and we propose that these distinct lineages should be ranked as genera.

We propose to use the name Raphitoma for the clade containing $R$. pseudohystrix (believed to be the closest extant relative of the type species of Raphitoma), $R$. bicolor, $R$. cordieri, $R$. densa, $R$. horrida, $R$. laviae, $R$. maculosa, $R$. philberti and $R$. purpurea. We note that a strongly supported sister-group relationship of $R$. pseudohystrix to the other species in the sublineage was recovered in some analyses. We also note that $R$. pseudohystrix never formed a clade with other morphologically similar spiny-shelled raphitomids, such as $R$. cordieri and $R$. horrida.

The clade comprising $R$. linearis, $R$. aequalis and $R$. obesa may be the sister group of Raphitoma s. s., but this relationship was strongly supported in only three of the eight analyses we carried out. We propose, therefore, to treat the clade of $R$. linearis, $R$. aequalis and $R$. obesa as a distinct genus for which the name Cyrillia Kobelt, 1905 is available (see Systematic Descriptions, below). Our results show that the $R$. leufroyi $+R$. concinna lineage is not nested within the clade that contains most of the Raphitoma species or the clade of $R$. linearis $+R$. aequalis $+R$. obesa. We use the generic name Leufroyia Monterosato, 1884 for the $R$. leufroyi $+R$. concinna lineage.

Raphitoma corimbensis was not related to any of these lineages (Raphitoma, Cyrillia or Leufroyia) and, as suggested by its shell morphology (and by that of its certainly close relative, $R$. bedoyai Rolán, Otero-Schmitt \& Fernandes, 1998), further studies on its systematic position should explore the relationship between this species and lineages currently placed in the genus Daphnella Hinds, 1844 (which may prove to be polyphyletic). We suggest a provisional classification of $R$. corimbensis and $R$. bedoyai in Paradaphne Laseron, 1954 (type species: Daphnella botanica Hedley, 1922 by original designation), which is currently ranked as a subgenus of Daphnella Hinds, 1844. The rationale for this classification is that the shell features of the type species of Paradaphne is strikingly similar to $R$. bedoyai and $R$. corimbensis.

Our findings suggest that Raphitoma rubroapicata (E.A. Smith, 1885), and the 'Raphitoma' sp. (IM-2007-17882) do not belong in the genus Raphitoma, but further work involving broader taxon sampling is needed to clarify their relationships.

On the basis of the phylogenetic results presented here and shell morphological data, we propose the following new classification for the bulk of Mediterranean/East Atlantic species currently ascribed to Raphitoma s. l., as previously conceived. 
Table 2. List of Recent species of the genus Raphitoma with their geographic range (NEA, North East Atlantic; WA, West Africa; Mac, Macaronesia; Med, Mediterranean) and the type of protoconch (m, multispiral; $\mathrm{p}$, paucispiral).

\section{Species}

R. alida Pusateri \& Giannuzzi-Savelli, 2016

$R$. alleryana (Sulliotti, 1889)

$R$. alternans (Monterosato, 1884)

$R$. arnoldi (Pallary, 1906)

R. atropurpurea (Locard \& Caziot, 1900)

$R$. bartolinorum Pusateri \& Giannuzzi-Savelli, 2018

$R$. bernardoi Rolán, Otero-Schmitt \& Fernandes, 1998

* R. bicolor (Risso, 1826) = R. maculosa Høisæter, 2016

$R$. bourguignati (Locard, 1891)

R. bracteata (Pallary, 1904)

R. brunneofasciata Pusateri, Giannuzzi-Savelli \& Oliverio, 2013

R. christfriedi Rolán, Otero-Schmitt \& Fernandes, 1998

$R$. contigua (Monterosato, 1884)

R. corbis (Potiez \& Michaud, 1838)

* R. cordieri (Payraudeau, 1826)

* R. densa (Monterosato, 1884)

R. digiulioi Pusateri \& Giannuzzi Savelli, 2017

R. ebreorum Pusateri \& Giannuzzi-Savelli, 2018

R. echinata (Brocchi, 1814) sensu Auctores

R. farolita F. Nordsieck, 1977

$R$. formosa (Jeffreys, 1867)

R. griseomaculata Pusateri \& Giannuzzi-Savelli 2018

R. hispida (Monterosato, 1890)

* R. horrida (Monterosato, 1884)

R. kharybdis Pusateri \& Giannuzzi-Savelli, 2018

* R. laviae (Philippi, 1844)

$R$. lineolata (Bucquoy, Dautzenberg \& Dollfus, 1883)

R. locardi Pusateri, Giannuzzi-Savelli \& Oliverio, 2013

* R. maculosa Høisæter, 2016 [=? R. bicolor]

R. mirabilis (Pallary, 1904)

$R$. nivea (J. T. Marshall in Sykes, 1906)

$R$. oblonga (Jeffreys, 1867)

$R$. papillosa (Pallary, 1904)

* R. philberti (Michaud, 1829)

R. pruinosa (Pallary, 1906)

* R. pseudohystrix (Sykes, 1906)

R. pumila (Monterosato, 1890)

$R$. pupoides (Monterosato, 1884)

* R. purpurea (Montagu, 1803)

$R$. radula (Monterosato, 1884)

R. skylla Pusateri \& Giannuzzi-Savelli, 2018

R. smriglioi Pusateri \& Giannuzzi-Savelli, 2013

R. spadiana Pusateri \& Giannuzzi-Savelli, 2012

R. strucki (Maltzan, 1883)

R. syrtensis F. Nordsieck, 1977

R. zelotypa Rolán, Otero-Schmitt \& Fernandes, 1998

NEA WA Mac Med P

$\begin{array}{cccc} & & + & \mathrm{p} \\ & & + & \mathrm{p} \\ & & + & \mathrm{p} \\ & + & \mathrm{p} \\ + & + & \mathrm{m} \\ & + & & \mathrm{p} \\ & & + & \mathrm{m}\end{array}$

$+\quad+\quad+\quad m$

$+\quad+m$

$+\mathrm{p}$

$+\mathrm{m}$

$+\quad+\quad \mathrm{m}$

$+\quad+\quad \mathrm{m}$

$+\mathrm{m}$

$+\quad+\quad+\quad+m$

$++\mathrm{m}$

$+\mathrm{m}$

$\begin{array}{rrr} & + & \mathrm{m} \\ +\quad+\quad & + & \mathrm{m}\end{array}$

$+\mathrm{p}$

$+\quad \mathrm{m}$

$+\quad \mathrm{p}$

$+\mathrm{m}$

$+p$

$+p$

$+\mathrm{m}$

$+m$

$+m$

$m$

$+\quad \mathrm{p}$

$+p$

$+\quad \mathrm{m}$

$+\mathrm{p}$

$+\quad+\quad \mathrm{p}$

$+\mathrm{p}$

$+\quad+\mathrm{p}$

$+\mathrm{m}$

$+\quad \mathrm{m}$

$+\quad \mathrm{m}$

$+m$

$+\mathrm{m}$

$+p$

$+\mathrm{p}$

$+\quad$ ?

Species included in our molecular systematic analyses are indicated by an asterisk. 


\section{SYSTEMATIC DESCRIPTIONS}

\section{Family RAPHITOMIDAE Bellardi, 1875 \\ Genus Raphitoma Bellardi, 1847}

(Fig. 1A-D; Table 2)

Raphitoma Bellardi, 1847: 612. [type species Raphitoma histrix Bellardi, 1847 (ex Pleurotoma hystrix Cristofori \& Jan, 1832, nomen nudum) SD, Monterosato, 1872: 54].

Homotoma Bellardi, 1875: 22 (type species Murex reticulatus Renier, 1804; SD, Powell, 1966). Cordieria Monterosato, 1884: 131 (type species Murex reticulatus Renier, 1804.; SD, Crosse, 1885; erroneously credited to Brocchi, 1814, ICZN, 1999, Art. 67.7; not Rouault, 1848). Philbertia Monterosato, 1884: 132 (type species Pleurotoma bicolor Risso, 1826; SD, Crosse, 1885). Peratotoma Harris \& Burrows, 1891: 113 (replacement name for Homotoma Bellardi, 1875, not Guérin-Ménéville, 1844). Cyrtoides F. Nordsieck, 1968: 176 [type species Pleurotoma rudis Scacchi, 1836 (not G.B. Sowerby I, 1834; renamed Cordieria pupoides Monterosato, 1884 and Raphitoma neapolitana F. Nordsieck, 1977) OD].

Diagnosis: Shell small to medium size for family, ranging in height from $5 \mathrm{~mm}$ (R. laviae) to 25 $\mathrm{mm}$ (R. cordieri, $R$. bourguignati); shape turreted to biconic-pupoidal; suture impressed.

Protoconch: if multispiral, then 3-4.5 whorls, with protoconch I (embryonic shell) of 0.5-0.7 whorls, with reticulate sculpture of spirals and orthocline axial striae, and protoconch II (larval shell) of 2.3-3.5 whorls, with diagonally cancellate sculpture and often keeled last whorl; if paucispiral, then of 2 whorls, with large nucleus and reticulate sculpture. Teleoconch with slender spire of 5 ( $R$. brunneofasciata) to 9 ( $R$. cordieri) uniformly convex whorls; reticulate-cancellate sculpture, axials broader than spirals. Fine granular microsculpture occasionally present on whole teleoconch ( $R$. papillosa) or on first whorl only ( $R$. philberti). Outer lip thickened, with 7-13 inner denticles. Columella simple, slightly sinuous anteriorly. Siphonal canal very short $(R$. contigua) to moderately long (R. cordieri). Siphonal notch wide, plain or intorted.

Remarks: As type species of Cordieria, Crosse (1885) designated 'Murex reticulatus Brocchi, 1814' (following the indication by Monterosato: 1884: 131 " C. reticulata, (Ren.) Brocc. / = Murex reticulatus ed echinatus, Brocc. - 1814, p. 423, t. 8, f. 3"). However, Murex reticulatus Brocchi (1814: 435, pl. 9, fig. 12) is not a raphitomid, but a species of Genota Gray, 1847 (Borsoniidae). It is clear that Monterosato (1884: 131) confused Murex reticulatus Brocchi with M. reticulatus Renier (which is also invalid: ICZN, 1999: Op. 316); the latter is probably the same as Murex echinatus Brocchi, 1814 (=Raphitoma echinata) and it was this species that Monterosato (1884) was indicating. Therefore, we retain Crosse's (1885) designation but as an incorrect citation (ICZN, 1999: Art. 67.7) and use Renier's name which, even if unavailable, can be designated as the type species for Cordieria and Homotoma; see ICZN, 1999: Art 67.1.2).

The phylogenetic results presented here do not support any further splitting of this genus. In this respect in it important to note that the species traditionally ascribed to the 'genera' Philbertia and Cordieria (=Peratotoma) are distributed across the tree. Similarly, the grouping of species in the phylogeny does not correspond to differences in larval development (as indicated by their multispiral or paucispiral protoconch), and this is consistent with the currently accepted view that larval development is not a reliable taxonomic character at the genus level (Bouchet, 1990). The genetic distance between Raphitoma maculosa and $R$. bicolor is small $(<1 \%)$, and this level of variation could well fall within the variation of the latter species when a denser sampling of $R$. bicolor is carried out. In contrast, our phylogenetic data indicate that a DNA-barcode-based approach could potentially be used to discriminate between closely related species of Raphitoma (e.g. $R$. philberti and $R$. densa in the COI phylogeny; see Supplementary Material Figs S1, S2). 
DNA barcodes should be used in combination with shell morphology to define species limits in this difficult group of neogastropods.

Table 3. List of Recent species of the genus Cyrillia with their geographic range (NEA, North East Atlantic; WA, West Africa; Mac, Macaronesia; Med, Mediterranean) and the type of protoconch (m, multispiral; p, paucispiral).

\section{Species}

* C. aequalis (Jeffreys, 1867)

C. ephesina (Pusateri, Giannuzzi-Savelli \& Stahlschmidt, 2017)

C. kabuli (Rolán, Otero-Schmitt \& Fernandes, 1998)

* C. linearis (Montagu, 1803)

* C. obesa (Høisæter, 2016) [=? C. aequalis]

C. zamponorum (Horro, Gori \& Rolán, 2019)

NEA WA Mac Med $\mathbf{P}$

$+\quad+\quad+\quad m$

$+m$

Species included in our molecular systematic analyses are indicated by an asterisk.

\section{Genus Cyrillia Kobelt, 1905}

(Fig. 1J-M; Table 3)

Cirillia Monterosato, 1884: 133 [type species Murex linearis Montagu, 1803, SD Crosse, 1885; not Rondani, 1856 (Diptera)].

Cyrillia Kobelt, 1905: 367 (unjustified emendation of Cirillia Monterosato, 1884).

Cenodagreutes E. H. Smith, 1967: 1 (type species Cenodagreutes aethus E. H. Smith, $1967=$ Defranciaaequalis Jeffreys, 1867; OD). Lineotoma F. Nordsieck, 1977 (replacement name for Cirillia Monterosato, 1884, not Rondani, 1856).

Diagnosis: Shell small in size for family, from $5 \mathrm{~mm}$ (C. linearis) to $10 \mathrm{~mm}$ (C. ephesina); biconic, suture impressed. Protoconch 3.5-4 whorls, multispiral, with protoconch I (embryonic shell) of 0.50.7 whorls, with reticulate sculpture of spirals and orthocline axial striae, and protoconch II (larval shell) of 3.3-3.5 whorls, with diagonally cancellate sculpture and weakly keeled last whorl. Teleoconch with slender spire of 5 (C. linearis) to 7 (C. ephesina) convex whorls, with reticulatecancellate sculpture; axials broader than spirals. Microsculpture of granules or pustules; growth lines seldom obvious. Outer lip thickened, with 7-13 inner denticles, the 2 anterior-most stronger. Columella simple, slightly sinuous anteriorly. Siphonal canal short; siphonal notch plain.

Remarks: Cirillia Monterosato, 1884 is preoccupied by Cirillia Rondani, 1856, but the emended name Cyrillia Kobelt, 1905 is available, and has already been used (e.g. Ceulemans et al., 2018). This is a clear case of a demonstrably intentional emendation (ICZN, 1999: Art. 33.2), since the prescriptions of the Code are met: "there is an explicit statement of intention" ... and "both the original and the changed spelling are cited and the latter is adopted in place of the former" (ICZN, 1999: Art. 33.2.1). As an intentional, yet unjustified emendation, the name that should be used is Cyrillia Kobelt, 1905 (ICZN, 1999: Art. 33.2.3).

Cirillia aequalis and $C$. linearis lack radula and venom gland. Our phylogenetic results suggest that denser sampling may show $C$. obesa to be simply a colour variant of $C$. aequalis. Cyrillia zamponorum from São Tomé Island and another probably undescribed species from Madagascar (N. Puillandre \& M. Oliverio, unpubl.) indicate that this lineage has a wide geographical distribution.

Table 4. List of Recent species of the genus Leufroyia with their geographic range (NEA, North East Atlantic; WA, 
West Africa; Mac, Macaronesia; Med, Mediterranean) and the type of protoconch (m, multispiral; $\mathrm{p}$, paucispiral).

\section{Species}

* L. concinna (Scacchi, 1836)

L. erronea Monterosato, 1884

* L. leufroyi (Michaud, 1828)

L. villaria (Pusateri \& Giannuzzi-Savelli, 2008)

\begin{tabular}{lllll} 
NEA & WA & Mac & Med & P \\
\hline+ & & + & + & $\mathrm{m}$ \\
& & & + & $\mathrm{m}$ \\
+ & + & + & + & $\mathrm{m}$ \\
& + & & + & $\mathrm{m}$ \\
\hline
\end{tabular}

Species included in our molecular systematic analyses are indicated by an asterisk.

\section{Genus Leufroyia Monterosato, 1884}

(Fig. 1E-I; Table 4)

Leufroyia Monterosato, 1884: 134 (type species Pleurotoma leufroyi Michaud, 1828; SD Crosse, 1885).

Diagnosis: Shell medium to large size for family, from $15 \mathrm{~mm}$ (L. concinna) to $24 \mathrm{~mm}$ (L. villaria); shape suboval (L. erronea) to fusiform (L. leufroyi). Protoconch of 3-3.5 whorls with protoconch I (embryonic shell) of $0.5-0.7$ whorls, with reticulate sculpture of spirals and orthocline axial striae, and protoconch II (larval shell) of 2.5-3 whorls, with diagonally cancellate sculpture, sometimes lightly keeled last whorl. Teleoconch with slender spire of 5 (L. concinna) to 7 (L. villaria) uniformly convex whorls; sculpture of thin, numerous low spiral cords and broader, wavy axial ribs. Microsculpture of dense, rather conspicuous growth lines, or rugae; no granules or pustules. Inner lip smooth with no denticles. Columella simple, slightly sinuous anteriorly. Siphonal canal short $(L$. erronea) to moderately long (L. leufroyi); siphonal notch wide, plain.

Remarks: The protoconch is wider (diameter $=c .220-250 \mu \mathrm{m}$ ) and lower than in the 'multispiral' propoconch of species of Raphitoma and Cyrillia.

\section{ACKNOWLEDGEMENTS}

We thank Jean Louis Delemarre, Michel Le Quement, Constantin Mifsud and Jakov Prkić for providing critical specimens for our molecular work. Extralimital material was collected as part of the MNHN Tropical Deep-Sea Benthos (Aurora, BOA1, EBISCO, Salomon 2) and Our Planet Reviewed (Papua Niugini, Santo 2006) programmes, or stand-alone expeditions (Panglao 2004); Bouchet (2009) and Bouchet et al. (2008, 2016) provide details on the context of the expeditions and the partnerships involved. All expeditions operated under permits provided by the host countries and satisfy the conditions set by the Convention on Biological Diversity for access to genetical resources. Stefano Bartolini, Vittorio Garilli, Andrea Nappo and Bruno Sabelli provided help with photography. Part of the molecular work was conducted by Louise Lindblom in the DNA $\mathrm{Lab}$ at the University of Bergen. SEM photos were taken at the Laboratory of Technological and Functional Analyses of Prehistoric Artifacts of Sapienza University of Rome, with the kind help of Cristina Lemorini (Department of Classics). The work was funded partly by the Sapienza University of Rome (grant AR11715C7E17226C/2017 to VR and RM11715C818F7955/2017 to MO). Virginie Héros and Philippe Bouchet (MNHN) commented on initial drafts of the manuscript; two anonymous reviewers provided constructive feedback; and David Reid suggested a number of editorial improvements.

\section{REFERENCES}


AARTSEN, J.J. VAN, MENKHORST, H.P.M.G. \& GITTENBERGER, E. 1984. The marine Mollusca of the Bay of Algeciras, Spain, with general notes on Mitrella, Marginellidae and Turridae. Basteria, Supplement 2: 1-135.

ABDELKRIM, J., AZNAR-CORMANO, L., FEDOSOV, A. E., KANTOR, Y. I., LOZOUET, P., PHUONG, M. A., ZAHARIAS, P. \& PUILLANDRE, N. 2018. Exon-capture-based phylogeny and diversification of the venomous gastropods (Neogastropoda, Conoidea). Molecular Biology and Evolution, 35: 2355-2374.

BARCO, A., RAUPACH, M.J., LAAKMANN, S., NEUMANN, H. \& KNEBELSBERGER, T. 2016. Identification of North Sea molluscs with DNA barcoding. Molecular Ecology Resources, 16: 288-297

BELLARDI, L. 1847 [1848]. Monografia delle Pleurotome fossili del Piemonte. Memorie della Reale Accademia delle Scienze di Torino, serie 2, 9: 531-650, pls 1-4. [Journal issue published in 1848, but a separate distributed in 1847 as: Monografia delle Pleurotome Fossili del Piemonte. Torino].

BONFITTO, A., \& MORASSI, M. 2013. New Indo-Pacific species of Rimosodaphnella Cossmann, 1916 (Gastropoda: Conoidea): a genus of probable Tethyan origin. Molluscan Research, 33: 230-236.

BOUCHET, P. 1990. Turrid genera and mode of development: the use and abuse of protoconch morphology. Malacologia, 32: 69-77.

BOUCHET, P., 2009. From specimens to data, and from seashells to molluscs: the Panglao Marine Biodiversity Project. Vita Malacologica, 8: 1-8.

BOUCHET, P., HEROS, V., LOZOUET, P. \& MAESTRATI, P. 2008. A quarter-century of deepsea malacological exploration in the South and West Pacific: Where do we stand? How far to go? Tropical Deep-Sea Benthos, Volume 25. Mémoires du Muséum National d'Histoire Naturelle, 196: 9-40.

BOUCHET, P., LE GUYADER, H. \& PASCAL, O. 2011. The "making of" Santo 2006.Patrimoines Naturels, 70: 529-548.

BOUCHET, P., KANTOR, Y.I., SYSOEV, A. \& PUILLANDRE, N. 2011. A new operational classification of the Conoidea. Journal of Molluscan Studies, 77: 273-308.

CABANG, A.B., IMPERIAL, J.S., GAJEWIAK, J., WATKINS, M., CORNELI, P.S., OLIVERA, B.M. \& CONCEPCION, G.P. 2011. Characterization of a venom peptide from a crassispirid gastropod. Toxicon, 58: 672-680

CASTRESANA, J. 2000. Selection of conserved blocks from multiple alignments for their use in phylogenetic analysis. Molecular Biology and Evolution, 17: 540-552.

CEULEMANS, L., VAN DINGENEN, F. \& LANDAU, B.M. 2018. The lower Pliocene gastropods of Le Pigeon Blanc (Loire- Atlantique, northwest France). Part 5 - Neogastropoda (Conoidea) and Heterobranchia (fine). Cainozoic Research. 18: 89-176.

CROSSE, H. 1885. Nomenclature generica e specifica di alcune Conchiglie Mediterranee, pel marchese di Monterosato. Journal de Conchyliologie, 33: 139-142.

DALL, W.H. 1918. Notes on the nomenclature of the mollusks of the family Turritidae. Proceedings of the United States National Museum, 54: 313-333.

ESPIRITU, D.J.D., WATKINS, M., DIA-MONJE, V., CARTIER, G.E., CRUZ, L.J., OLIVERA, B.M., 2001. Venomous cone snails: molecular phylogeny and the generation of toxin diversity. Toxicon 39: 1899-1916.

FEDOSOV, A.E., PUILlANDRE, N., KANTOR, Y.I. \& BOUCHET, P. 2015. Phylogeny and systematics of mitriform gastropods (Mollusca: Gastropoda: Neogastropoda). Zoological Journal of the Linnean Society, 175: 336-359.

FEDOSOV, A.E., STAHLSCHMIDT, P., PUILLANDRE, N., AZNAR-CORMANO, L. \& BOUCHET, P. (2017). Not all spotted cats are leopards: evidence for a Hemilienardia ocellata species complex (Gastropoda: Conoidea: Raphitomidae). European Journal of Taxonomy, 268: 1-20. 
FISCHER, P. 1880-1887. Manual de conchyliologie et de paléontologie conchyliologique. Vol. xx. Savy, Paris.

FOLMER, O., BLACK, M., HOEH, W., LUTZ, R. \& VRIJENHOEK, R., 1994. DNA primers for amplification of mitochondrial cytochrome $\mathrm{c}$ oxidase subunit I from diverse metazoan invertebrates. Molecular Marine Biology and Biotechnology, 3: 294-299.

GIANNUZZI-SAVELLI, R., PUSATERI, F. \& BARTOLINI, S. 2018. A revision of the Mediterranean Raphitomidae (Gastropoda: Conoidea) 5: loss of planktotrophy and pairs of species, with the description of four new species. Bollettino Malacologico, 54 (Suppl 11): 177.

HARRIS, G.F. \& BURROWS, H.W. 1891. The Eocene and Oligocene beds of the Paris Basin. University College, London.

HAYASHI, S., 2003. The molecular phylogeny of the Buccinidae (Caenogastropoda: Neogastropoda) as inferred from the complete mitochondrial 16S rRNA gene sequences of selected representatives. Molluscan Research, 25: 85-98.

HØISÆTER, T. 2016. A taxonomic review of the Norwegian species of Raphitoma (Gastropoda: Conoidea: Raphitomidae). Fauna Norvegica, 36: 9-32.

HORRO, J., GORI, S. \& ROLÁN, E. 2019. Raphitoma zamponorum a new species from São Tomé Island (Gastropoda: Raphitomidae). Iberus, 37: 1-6.

HUELSENBECK, J.P. \& RONQUIST, F. 2001. MrBAYES: Bayesian inference of phylogenetic trees. Bioinformatics, 17: 754-755.

KANTOR, YU.I. \& TAYLOR, J.D. 2002. Foregut anatomy and relationships of raphitomine gastropods (Gastropoda: Conoidea: Raphitominae). In: Systematics, phylogeny and biology of the Neogastropoda (M. Oliverio \& R. Chemello, eds). Bollettino Malacologico, Supplement 5: 161-174.

KATOH, K., ROZEWICKI, J. \& YAMADA K.D. 2017. MAFFT online service: multiple sequence alignment, interactive sequence choice and visualization. Briefings in Bioinformatics, 30: 3059 .

KEARSE, M., MOIR, R., WILSON, A., STONES-HAVAS, S., CHEUNG, M., STURROCK S., BUXTON S., COOPER A., MARKOWITZ S., DURAN C., THIERER T., ASHTON B., MEINTJES, P. \& DRUMMOND, A. 2012. Geneious Basic: an integrated and extendable desktop software platform for the organization and analysis of sequence data. Bioinformatics, 28: $1647-1649$.

KOBELT, W. 1905 1887-1908. Iconographie der schalentragenden europäischen Meeresconchylien. Part 3: 1-24, pls 59-62 [1902]; 25-200, pls 63-78 [1903]; 201-272, pls 7984, 86-87 [1904]; 273-406 [1905]. T. Fischer, Cassel.

KURAKU, S., ZMASEK, C.M., NISHIMURA, O. \& KATOH, K. 2013. aLeaves facilitates ondemand exploration of metazoan gene family trees on MAFFT sequence alignment server with enhanced interactivity. Nucleic Acids Research, 41: W22-W28.

MANOUSIS, T., KONTADAKIS, C., MBAZIOS, G., \& POLYZOULIS, G. 2018. The family Raphitomidae (Mollusca: Gastropoda: Conoidea) in the Greek Seas with the description of two new species. Journal of Biological Research-Thessaloniki, 25: 14.

MILLER, J.A. 1989. The toxoglossan proboscis: structure and function. Journal of Molluscan Studies, 55: 167-182.

MILLER, M.A., PFEIFFER, W. \& SCHWARTZ, T. 2010. Creating the CIPRES Science Gateway for inference of large phylogenetic trees. In: Proceedings of the Gateway Computing Environments Workshop (GCE), 14 November 2010, New Orleans, LA, pp 18.MONTEROSATO T.A. di 1872. Notizie intorno alle conchiglie Mediterranee. Michele Amenta, Palermo.

MONTEROSATO T.A. di 1884. Nomenclatura generica e specifica di alcune conchiglie mediterranee. Virzi, Palermo.

NORDSIECK, F. 1968. Die europäischen Meeres-Gehäuseschnecken (Prosobranchia). Vom 
Eismeer bis Kapverden und Mittelmeer. Gustav Fischer, Stuttgart..

NORDSIECK, F. 1977. The Turridae of the European Seas. Ed. La Piramide, Rome.

OLIVERIO, M. 1995. The systematics of the radula-less gastropod Clathromangelia (Caenogastropoda, Conoidea). Zoologica Scripta, 24: 193-201.

OLIVERIO, M., \& MARIOTTINI, P. 2001. A molecular framework for the phylogeny of Coralliophila and related muricoids. Journal of Molluscan Studies, 67: 215-224.

PLOUVIEZ, S., JACOBSON, A., WU M. \& VAN DOVER, C.L. 2015. Characterization of vent fauna at the Mid-Cayman Spreading Center. Deep-Sea Research I, 97: 124-133.

POSADA, D. 2008. JModelTest: phylogenetic model averaging. Molecular Biology and Evolution, 25: $1253-1256$.

POWELL, A.W.B. 1966. The molluscan families Speightiidae and Turridae. An evaluation of the valid taxa both recent and fossil, with lists of characteristic species. Bulletin of the Auckland Institute and Museum 5: 1-184

PUILlANDRE, N., BOUCHET, P., DUDA, T.F. JR., KAUFERSTEIN, S., KOHN, A.J., OLIVERA, B.M., WATKINS, M. \& MEYER, C. 2014. Molecular phylogeny and evolution of the cone snails (Gastropoda, Conoidea). Molecular Phylogenetics and Evolution, 78C: 290-303.

PUILlANDRE, N., KANTOR, Y. I., SYSOEV, A., COULOUX, A., MEYER, C., RAWLINGS, T., TODD, J.A. \& BOUCHET, P. 2011. The dragon tamed? A molecular phylogeny of the Conoidea (Gastropoda). Journal of Molluscan Studies, 77: 259-272.

PUILLANDRE, N., SAMADI, S., BOISSELIER, M.C., SYSOEV, A.V., KANTOR, Y.I., CRUAUD, C., COULOUX, A. \& BOUCHET, P. 2008. Starting to unravel the toxoglossan knot: molecular phylogeny of the 'turrids' (Neogastropoda: Conoidea) Molecular Phylogenetics and Evolution, 47: 1122-1134.

ROLÁN, E., OTERO SCHMITT, J. \& FERNANDES, F. 1998. The family Turridae s.l. (Mollusca, Gastropoda) in Angola (West Africa), 1. Subfamily Daphnellinae. Iberus, 16: 95-118.

SHERIDAN, R., VAN MOL, J.-J. \& BOUILLON, J. 1973. Étude morphologique du tube digestif de quelques Turridae (Moll.-Gastr.-Prosobr.-Toxogl.) de la région de Roscoff. Cahiers de Biologie Marine, 14: 159-188.

SMITH, E.H. 1967. Two new species of British turrids. Veliger 10: 1-4.

STAMATAKIS, A. 2014. RAxML version 8: a tool for phylogenetic analysis and post-analysis of large phylogenies. Bioinformatics, 30: 1312-1313.

TAYLOR, J.D., KANTOR, Y.I. \& SYSOEV, A.V. 1993. Foregut anatomy, feeding mechanisms, relationships and classification of Conoidea (Toxoglossa) (Gastropoda). Bulletin of the Natural History Museum, London (Zoology), 59: 125-170. 